Review Articles

\title{
Withholding Certificates and Self-Certifications under FATCA
}

\author{
Stefan Kaestli \\ Institute of Economics of the Polish Academy of Sciences, Warsaw, Poland
}

Article history

Received: 6-01-2015

Revised: 3-02-2015

Accepted: 17-04-2015

Email: stefan.kaestli@kaestli.name

\begin{abstract}
This review article analyzes the term withholding certificate and self-certification under the Foreign Account Tax Compliance Act (FATCA). It shows which types of forms exist in order to establish an account holder's FATCA status (chapter 4 status). It proofs in particular under which conditions a Participating Foreign Financial Institution may use its own form in lieu of an official IRS form.
\end{abstract}

Keywords: FATCA, Chapter 4, Withholding Certificate, Self-Certification, Written Statement, Documentary Evidence, Self Declaration

\section{Introduction}

The main goal of the FATCA regulation consists in gathering data of Financial Accounts held by U.S. tax residents living outside the United States. An integral part of that process is the documentation of each such account holder's FATCA status (hereafter: chapter 4 status). The chapter 4 status shall be established based on the due diligence procedures described in annex I of the appropriate Intergovernmental Agreement (hereafter: IGA) or in the Treasury Regulations (hereafter: Treas. Reg.). A participating FFI (hereafter: PFFI) is required to establish the status of each holder of a U.S. account. A U.S. account is any Financial Account maintained by an FFI that is held by one or more specified U.S. persons or U.S. owned foreign entities (see Treas. Reg. §1.14711(b)(134) referring to $\$ 1.1471-5(a))$. Such a classification may sometimes be done based on the information obtained in connection with the opening of the account, including any documentation collected pursuant to $\mathrm{AML} / \mathrm{KYC}$ procedures or based on a selfcertification that must be issued by the account holder in written form (see Treas. Reg. §1.1471-1(a) for the scope of chapter 4 of the Internal Revenue Code). A Participating FFI would be subject to the due diligence procedures in the Treas. Reg. provided it is not governed by any Model 1 or Model 2 IGA, whereas a Reporting M1 or M2 IGA FFI (hereafter: PFFI) would be subject to the due diligence procedures in Annex I of their IGA. This review article does not separate between a Reporting M1 or M2 FFI and a participating FFI. All such FFIs are hereafter called PFFIs.

\section{The Obligation to Establish an Account Holders FATCA Status}

Data gathering is important and mandatory by law for all U.S. accounts (including such accounts that must be threat like U.S. accounts) and for certain payments, i.e., for earnings that are chapter 4 reportable amounts.

\section{For Accounts}

A PFFI is required to obtain such information regarding each holder of each account maintained by the PFFI to determine whether each account is a U.S. account or an account held by a recalcitrant account holder or nonparticipating FFI in accordance with the due diligence procedures for identifying and documenting account holders described in Treas. Reg. $\S 1.1471-4(\mathrm{a})(2)$ (referring to $\S 1.1471-4(\mathrm{c})$ referring to $\S 1.1471-4(\mathrm{c})(2))$.

\section{For Payments}

Except as otherwise provided, a withholding agent must base its determination of the chapter 4 status of a payee on documentation that the withholding agent can reliably associate with such payment. If a withholding agent makes a payment to a person that is not the payee, the withholding agent will be required to determine the chapter 4 status of each intermediary or flow-through entity in the payment chain until the withholding agent is able to identify the payee. This is the so-called lookthrough principle which was introduced under FATCA. It obliges a U.S. withholding agent to identify the ultimate U.S. beneficial owner of a payment that is U.S. 
FDAP.Treas. Reg. $§ 1.1471-3(\mathrm{c})$ provides rules for when a withholding agent can reliably associate a payment with appropriate documentation (see Treas. Reg. $\S 1.1471-3$ (b) refering to $\S 1.1471-3(\mathrm{c})$ ).

\section{Fundamental Obligation for Account Holder Identification}

As a first perception, a participating FFI is required to identify among all accounts that it maintains each account that is a U.S. account or a Financial Aaccount held by a recalcitrant account holder or nonparticipating FFI (hereafter: NPFFI) (see Treas. Reg. §1.1471-4(c)(2)(i)). In addition, a PFFI must identify each payee of a payment that is U.S. FDAP (see Treas. Reg. $\$ 1.1471-3(b)$ ). In most cases, the payee of such a payment is the same person as the holder of a U.S. account.

\section{Due Diligence Procedures for the Identification and Documentation of Account Holders and Payees}

The account holders chapter 4 status may be determined in different ways which mainly depends on the type of the account in question. The regulations separate between preexisting and new accounts on the one hand and between individual accounts and entity accounts on the other hand.

A participating FFI shall determine the status of each account by applying the due diligence procedures in the annex I of the appropriate IGA. That allows the PFFI to determine such a status without involvement of the account holders in certain situations. Alternatively, it may have the account holders to declare themselves their status. In the case of the opening of a new Financial Account, a PFFI is typically better off by having the account holders to declare their chapter 4 status by submitting a valid withholding certificate (may be part of the account opening documentation). In the case of preexisting Financial Accounts, the withholding certificate (may be in the form of a self-certification) is typically to revoke or confirm U.S. indicia that were found during the account screening process. For that reason, this article focuses purely on the self-declaration process with help of self-declarations. The term "self-declaration" exists neither in the Treas. Reg. nor in any IGA. The industry commonly refers to the term self-declaration situations in which an account holder declares his or her chapter 4 status with help of a self-certification.

An account holder shall in the first step declare his chapter 4 status. The second step, he shall confirm his declaration in written form. Such a declaration and certification is generally done with help of a withholding certificate that is signed by the account holder under penalties of perjury. In certain situations, such self declarations may be done with an acceptable substitute form that has to be signed by the account holder but without the perjury clause and in certain situations a withholding agent may ask the account holders or payees to sign a written statement instead.

\section{Declaration of the Chapter 4 Status with a Withholding Certificate - for PFFIs that follow the Treasury Regulations}

This chapter describes how a chapter 4 status may be determined under the Treasury Regulations. A PFFI that is governed by an IGA may follow this approach or it may follow the approach that is described in the applicable IGA. A PFFI that is not governed by any IGA must follow the approach that is described hereafter.

Under the Treasury Regulations, an account holder declares its chapter 4 status generally with help of a withholding certificate or any other certificate that under the Code or regulations certifies or establishes the chapter 4 status of a payee or beneficial owner.

\section{Meaning of the Term Withholding Certificate}

The term withholding certificate means (see Treas. Reg. $§ 1.1471-1(b)(148))$ :

- A form W-8,

- A form W-9, or

- Any other certificate that under the Code or regulations certifies or establishes the chapter 4 status of a payee or beneficial owner. (This is a very important point: any certificate that establishes under the code or the regulations thereunder an account holder's chapter 4 status is a withholding certificate. That includes not only IRS forms.)

The "Code" means the "Internal Revenue Code" which is in Title 26 of the United States Code (26 U.S.C.) The "regulations" means the "Treasury Regulations". Treasury regulations (26 C.F.R.), commonly referred to as Federal tax regulations, pick up where the Internal Revenue Code (IRC) leaves off by providing the official interpretation of the IRC by the U.S. Department of the Treasury (IRS, 2014; 2015a). The regulations sometimes refer to the applicable Intergovernmental Agreements. As an example: A PFFI from a Model 2 jurisdiction is free to follow the identification due diligence procedures in the applicable Model 2 Intergovernmental Agreement (see Treas. §1.1471-4(c)(1)).

In spite of the above definition, it may not be entirely clear what the term withholding certificate means. A withholding certificate under chapter 3 is used in these situations: Aliens who wish to claim various exemptions from withholding tax on U.S. source income, or who wish to notify their withholding agents of their U.S. or foreign status are often required to file withholding 
certificate forms. Such forms may be: Form W-8BEN, Form W-8ECI, Form W-8EXP, Form W-8IMY, Form W-9 and other forms (IRS, 2015b; 2015e).

An intermediary withholding certificate must be accompanied by a withholding statement described in $\S 1.1471-3(\mathrm{c})(3)(\mathrm{iii})(\mathrm{B})$ in order to be complete and valid (see Treas. Reg. §1.1471-2(a)(2)(iii)(A)(4)).

\section{Types of Withholding Certificates}

The Treasury Regulations describe what types of withholding certificates exist:

- (Beneficial owner) withholding certificate (form W8BEN/W-8BEN-E)

- Withholding certificate of an intermediary (form W8IMY)

- Certificate for exempt status (form W-8EXP)

- Certificate for effectively connected income (form W-8ECI)

- Request for taxpayer identification number and certification (form W-9)

- Substitute form for a withholding certificate

This review article does not describe the requirements for withholding certificates that are substitutes or replace-ments of the IRS form W-9 (see Treas. Reg. §1.1471-1(b)(148)).

\section{a) Official IRS Forms}

Withholding certificates are generally official IRS forms of the series W-8 and W-9. The withholding agents may accept in certain cases substitute forms for the official IRS forms.

\section{b1) A Substitute Form for a Withholding Certificate for Individual Account Holders}

A withholding agent may substitute its own form for an official form W-8BEN. A substitute form will be acceptable if it contains:

- The name and address of the individual that is the payee or beneficial owner

- All countries in which the individual is resident for tax purposes

- The individual's country of birth

- A tax identification number (if any) for each country of residence

- The individual's date of birth

A signed and dated certification made under penalties of perjury that the information provided on the form is accurate and will be updated by the individual within 30 days of a change in circumstances that causes the form to become incorrect.

Notwithstanding the previous sentence, the signed certification provided on a form need not be signed under penalties of perjury if the form is accompanied by documentary evidence that supports the individual's claim of foreign status (see Treas. Reg. §1.1471$3 \mathrm{~T}(\mathrm{c})(6)(\mathrm{v})(\mathrm{B}))$.

\section{b2) A Substitute Form for a Withholding Certificate for Entity Account Holders}

A withholding agent may substitute its own form for an official Form W-8BEN-E (and similar forms from the W-8 series that are for entity account holders). A substitute form will be acceptable if:

- It contains provisions that are substantially similar to those of the official form

- It contains the same certifications relevant to the transactions as are contained on the official form

- These certifications are clearly set forth and

- The substitute form includes a signature-underpenalties-of-perjury statement identical to the one on the official form

The substitute form must include any chapter 4 status for which withholding may apply, such as the categories for a nonparticipating FFI or passive NFFE. It is not required, though, that a substitute form includes all possible chapter 4 status.

A withholding agent that uses a substitute form must furnish instructions relevant to the substitute form only to the extent and in the manner specified in the instructions to the official form. A withholding agent may use a substitute form that is written in a language other than English and may accept a form that is filled out in a language other than English but the withholding agent must make available an English translation of the form and its contents to the IRS upon request. There is no exception from the signature-under-penalties-ofperjury statement for substitute forms for entity clients. A withholding agent may elect to accept or refuse any certificate (including any $\mathrm{W}-8$ ) from a person if the certificate provided is not an acceptable substitute form provided by the withholding agent (see Treas. Reg. $\$ 1.1471-3 \mathrm{~T}(\mathrm{c})(6)(\mathrm{v})(\mathrm{A}))$. The latter provisions means that the account holder may declare his chapter 4 status by use of a substitute form in lieu of an official IRS form only if the withholding agent is willing to accept such a substitute form.

\section{c) Written Statement}

The term written statement means a statement by the payee, or other person receiving the payment, that provides the person's chapter 4 status and any other information reasonably requested by the withholding agent to fulfill its obligations under chapter 4 with respect to the payment.

It must contain the following information on the person receiving the payment: 
- Name

- Address

- Certifications relevant to the person's chapter 4 status (as contained on a withholding certificate)

- Any additional information required with respect to the chapter 4 status (for example a GIIN)

- A signed and dated certification that the information provided on the form is accurate and will be updated by the individual within 30 days of a change in circumstances that causes the form to become incorrect

A written statement may be submitted in any form that is acceptable to the withholding agent (see Treas. Reg. §1.1471-1(b)(150) referring to $\$ 1.1471-3(c)(4))$. It is valid only if it is provided by a person with respect to an offshore obligation. A written statement may be submitted in any form that is acceptable to the withholding agent, including a statement made as part of the account opening documentation. A written statement may be used in lieu of a withholding certificate only to the extent provided under $\S 1.1471-3(d)$, as applicable to the chapter 4 status claimed (see Treas. Reg. $\$ 1.1471$ $3(c)(4)$ referring to $\$ 1.1471-3(d)$ referring to $\$ 1.1471$ 3(d)(1) through (12)):

- Reliance on pre-FATCA Form W-8 [\$1.14713(d)(1)]

- Identification of U.S. persons [\$1.1471-3(d)(2)]

- Reliance on documentary evidence [\$1.14713(d)(2)(ii)]

- $\quad$ Preexisting obligations $[\S 1.1471-3(d)(2)(i i i)]$

- Identification of individuals that are foreign persons [§1.1471-3(d)(3)]

- Identification of participating FFIs and registered deemed-compliant FFIs [\$1.1471-3(d)(4)]

- Identification of certified deemed-compliant FFIs $[\S 1.1471-3(\mathrm{~d})(5)]$

- Identification of owner-documented FFIs [\$1.1471$3(d)(6)]$

- $\quad$ Non reporting IGA FFIs [§1.1471-3(d)(7)]

- Identification of nonparticipating FFIs [\$1.1471$3(d)(8)]$

- Identification of exempt beneficial owners [\$1.14713(d)(9)]

- Identification of territory financial institutions [§1.1471-3(d)(10)]

- Identification of excepted NFFEs [\$1.1471$3(\mathrm{~d})(11)]$

- Identification of passive NFFEs [\$1.1471-3(d)(12)]

Treas. Reg. $§ 1.1471-3(d)(1)$ through (12) is a set of due-diligence procedures that may be applied by the PFFI in order to associate an offshore payment to an account holder or payee. These due-diligence procedures must be applied in addition to the written statement. Due to the varied procedures, it may be less complex for a PFFI to ask a withholding certificate from each account holder and from each payee instead of a written statement plus applying the applicable due diligence procedures.

\section{d) Withholding Statement}

A withholding statement forms an integral part of an intermediary withholding certificate. The most commonly used intermediary withholding certificate is an IRS form W-8IMY. It may be provided in any manner and in any form, to which the person submitting the form and the withholding agent mutually agree, including electronically.

It must be valid and be provided to the withholding agent prior to a payment (see Treas. Reg. §1.14713(c)(3)(iii)(B)(1)). Broadly speaking, a withholding statement indicates all necessary information on the payees of a payment, it allows a withholding agent to clearly allocate all parts of a withholdable payment with the corresponding account holders and their chapter 4 status.

For an example of a withholding statement see HSBC's withholding statement which is available online (HSBC, 2015).

\section{Meaning of the Term Documentary Evidence}

The term documentary evidence means documents, other than a withholding certificate or written statement, that a withholding agent is permitted to rely upon to determine the chapter 4 status of a person in accordance with §1.1471-3(c)(5) (see Treas. Reg. §1.1471-1(b)(32) referring to $[\S 1.1471-3(\mathrm{c})(5))$.

Acceptable documentary evidence supporting a claim of foreign status includes the following types of documentation:

- Certificate of residence [§1.1471-3(c)(5)(i)(A)]

- Individual government identification [\$1.1471$3(\mathrm{c})(5)(\mathrm{i})(\mathrm{B})]$

- QI documentation $[\S 1.1471-3(\mathrm{c})(5)(\mathrm{i})(\mathrm{C})]$

- Entity government documentation that is typically used for identification purposes [\$1.1471$3(\mathrm{c})(5)(\mathrm{i})(\mathrm{D})]$

- $\quad$ Third-party credit report [\$1.1471-3(c)(5)(i)(E)]

Documentary evidence may be required in certain circumstances in addition to withholding certificates or written statements. An account holder's chapter 4 status may not be determined based only on documentary evidence. 
Declaration of the Chapter 4 Status with a SelfCertification - for PFFIs that are governed by an IGA

This chapter describes how a chapter 4 status may be determined under the regulations of an Intergovernmental Agreement. A participating FFI that is governed by an IGA may follow this approach or it may follow the approach that is described in the Treasury Regulations. A participating FFI that is not governed by any IGA must not follow the approach that is described hereafter.

Under the Intergovernmental Agreements Model 1 and 2, an account holder declares its chapter 4 status generally with help of a self-certification.

\section{Meaning of the Term Self-Certification}

The term self-certification is not defined in any IGA. Instead, it is broadly described in several different paragraphs. As an example, see II(B)(4)(a)(1) annex I Model 2 IGA for individual accounts and see IV(D)(1)(b) for entity accounts. Broadly speaking, a self-certification under an IGA is a certification in which an account holder declares whether he is a U.S. resident for tax purposes or not. There is a misunderstanding in the market: many FFIs ask their account holders whether they are subject to U.S. taxes, which is the wrong question. FFIs can ask a person whether he or she is a U.S. resident for tax purposes, aka U.S. a person, aka a tax resident of the United States. (As an example: a foreign person may have a tax home in the United States and yet not be a tax resident of the United States. That would typically be the case if a foreign person posseses property in the United States. That matter of fact alone does not make one a U.S. tax payer but not necessarily a U.S. tax resident.) In fact, a self-certification declares an account holder's chapter 4 status in the case of an entity account holder or, his status of being a "U.S. person" or a foreign person in the case of an individual account holder (see article 1(y) Model 2 IGA). It does, however, not differentiate between "U.S. persons" and "specified U.S. persons".

\section{Types of Self-Certifications}

The term "self-certification" is described in several different ways in the IGAs:

- A self-certification (which may be on an IRS Form $\mathrm{W}-8$ or other similar agreed form). As an example, see II(B)(4)(a)(1) annex I Model 2 IGA.

- A self-certification (which may be an IRS Form W9 or other similar agreed form). As an example, see III(B)(1) annex I Model 2 IGA.

- A self-certification, which may be part of the account opening documentation. As an example, see III(B) annex I Model 2 IGA.
Any Intergovernmental Agreement may suggest a certain type of self-certification, depending on the situation. That does not mean that a PFFI must follow these recommendations. It is free to elect the type of selfcertification that it wants to use. As an alternative to the procedures described in each section of Annex I, PFFIs may rely on the procedures described in relevant U.S. Treasury Regulations to establish whether an account is a U.S. account or an account held by a Nonparticipating Financial Institution. As an example for Swiss FFIs, see article I(C) annex I IGA CH-USA (2015).

The wording "which may be on an IRS Form W-8 or other similar agreed form", " which may be an IRS Form W-9 or other similar agreed form" and "may be part of the account opening documentation" is only a recommendation. It does not imply in any way that in certain situations a W-8 or W-9 must be used. There is a broad misunderstanding in the market. Many PFFIs believe that they must use an IRS form W-8 when the IGA states "a self-certification (which may be on an IRS Form W-8 or other similar agreed form).

Such IRS recommendations may make sense in most situations because for preexisting Financial Accounts, a PFFI must only ask the account holders to declare their U.S. tax residence status in situations where it finds U.S. indicia in a client file. For new Financial Accounts, on the other hand, a PFFI must ask all account holders to declare their U.S. tax residence status, unless otherwise mentioned. (The IGAs do imply some thresholds for both preexisting and new accounts which allow a PFFI to disregard such accounts from reviewing, identifying and reporting.)

From an operational perspective, the best way to ask new account holders about their status may be to include a self-certification in the account opening documents. For preexisting account holders it is typically easier to send them a self-certification in the form of a withholding certificate or in the form of a similar agreed form (which equals to a substitute form for a withholding certificate).

If a PFFI decides not to include the selfcertification in the account opening documents, it may created its own self-certification, which is commonly referred to as a "self-declaration form". Such a selfdeclaration form is in fact a similar agreed form in the terminology of an IGA or a substantially similar form in the terminology of the Treasury Regulations - provided all of the legal provisions are followed and implemented.

\section{a) Official IRS Forms}

Official IRS forms may always be accepted as valid self-certifications under any Intergovernmental Agreement. In practice, the use of such forms may not be an option due to language barriers in certain jurisdictions; where not all account holders are able to understand English. 
b) A Similar Agreed Form $(I G A)=$ a Substitute Form (Treas. Reg.)

The term "similar agreed form" is neither defined nor described anywhere in an IGA or in the Treasury Regulations. The Internal Revenue Service (hereafter: IRS), however, do describe the term "similar agreed form" on one of their websites (IRS, 2015c).

A similar agreed form may include a substitute form:

- If its content is substantially similar to the IRS's official Form

- The partner jurisdiction does not decline such treatment

Generally, a similar agreed form in the wording of the IGA is the same as a substitute form in the wording of the Treasury Regulations (see Treas. Reg. § 1.1471$3(\mathrm{c})(6)(\mathrm{v})(\mathrm{A})$ for the requirements of a substitute withholding certificate).

Both Model 1 and Model 2 IGAs do not include any prohibitions for the useof a similar agreed form. A PFFI shall therefore check if there is any regulation in the applicable IGA that prohibits the use of a similar agreed form.

A similar agreed form in the IGA wording is the same as a substitute form for a withholding certificate as described in the Treasury Regulations.

\section{c) An Acceptable Self-Certification for Purposes of Annex I IGA}

In addition to the substitute form for the withholding certificate, the IRS accepts "an acceptable self-certification for purposes of the Annex I due diligence procedures for preexisting and new accounts" (hereafter: an acceptable self-certification for purposes of Annex I IGA) which includes at least the following information (IRS, 2015c):

- Name

- Date of birth (The date of birth is not a mandatory field for purposes of FATCA but it would make the self-certification valid for OECD Standard of Automatic Exchange of Financial Account Information.)

- Residence address for tax purposes

- (All) jurisdiction(s) of residence for tax purposes

- Taxpayer identification number (If taxpayer has both a U.S. TIN and a foreign TIN, the U.S. TIN must be provided and the foreign TIN may be provided.)

- In the case of an entity, the entity's chapter 4 status (An entity's FATCA status would include its status as a Nonparticipating FFI, Participating FFI,
Reporting Model 1 FFI, Reporting Model 2 FFI, Nonreporting IGA FFI, Active NFFE, Passive NFFE, etc.)

- In the case of a Passive NFFE, the name, residence address for tax purposes and taxpayer identification number with respect to any controlling person that is a specified U.S. person

An acceptable self-certification for purposes of Annex I IGA must, in order to be valid:

- Be signed (or otherwise positively affirmed) by the account holder

- Be dated by the account holder(at the latest at the date of receipt by the PFFI if it is not dated by the account holder)

- Include all previously mentioned information

Such an acceptable self-certification for purposes of Annex I IGA does not need to be certified under penalties of perjury and it seems there is no requirement for the account holders to inform the withholding agent within 30 days on any relevant information regarding the chapter 4 status (IRS, 2015d). Nonetheless, most PFFI do include a certification in their self-certification that the account must notify them within 30 days of any change in circumstance in order to assure their client files are always up-to-date.

An IGA jurisdiction planning to implement the OECD Standard for Automatic Exchange of Financial Account Information in Tax Matters (the Common Reporting Standard, CRS) may want the self-certification form to also require the account holder's date of birth. With this additional information, the self-certification form would be consistent with the Common Reporting Standard and the multilateral understanding of a valid self-certification.

There is no formal requirement to include a withholding statement in an acceptable self-certification for purposes of Annex I IGA. Nonetheless, that does not release a withholding agent from his duty to clearly allocate all parts of a chapter 4 withholdable payment with the corresponding account holders and to establish their chapter 4 status.

An acceptable self-certification for purposes of Annex I IGA may be the most suitable form for withholding agents from IGA jurisdictions, in particular for such in which English is not the official language or otherwise not spoken by most account holders. Its formal requirements are noticeably less restrictive than those on a substitute form or on an official IRS form. It is to note that such a type of a similar agreed form is not valid for all chapter 3 purposes. 
The market would generally refer to a "selfdeclaration" as an acceptable self-certification for purposes of Annex I IGA.

\section{Meaning of the Term Documentary Evidence}

The term documentary evidence is defined in paragraph D of section IV of the Annex I of Model 1 and 2 IGAs. For purposes of Annex I, acceptable documentary evidence includes any of the following:

- A certificate of residence issued by an authorized government body

- With respect to an individual, any valid identification issued by an authorized government body, that includes the individual's name and is typically used for identification purposes

- With respect to an entity, any official documentation issued by an authorized government body that includes the name of the entity and either the address of its principal office in the jurisdiction in which it claims to be a resident or the jurisdiction in which the entity was incorporated or organized,

- With respect to a Financial Account maintained in a jurisdiction with anti-money laundering rules that have been approved by the IRS in connection with a QI agreement, any of the documents, other than a form $\mathrm{W}-8$ or $\mathrm{W}-9$, referenced in the jurisdiction's attachment to the QI agreement for identifying individuals or entities

- Any financial statement, third-party credit report, bankruptcy filing, or U.S. Securities and Exchange Commission report

The term documentary evidence in an IGA is substantial similar to the definition in the Treas. Reg.

Documentary evidence may be required in certain circumstances in addition to withholding certificates or written statements. An account holder's chapter 4 status may not be determined based only on documentary evidence.

\section{Summary}

Asking an account holder about his U.S. tax residence status or asking about his chapter 4 status is generally done with help of a withholding certificate (if the withholding agent is governed by the Treas. Reg. or by an IGA) or with help of a self-certification (if the withholding agent is governed by an IGA). Neither form is "stronger" or "less strong" despite the fact that withholding certificates include a penalties-of-perjury-clause while self-certifications do not include such a clause.

After studying the legal provisions, it became apparent that the Treasury Regulations and the
Intergovernmental Agreements use different terms for similar purposes.

The Treasury Regulations use the following terms:

- Withholding certificates

- Written statements

- Documentary evidence

The Intergovernmental Agreements (both in Model 1 and Model 2 jurisdictions) use the following terms:

- Self-certification

- Documentary evidence

The terms "withholding certificate" and "selfcertification" are the ones that are literarlly different and yet similar in their meaning.

A withholding certificate is used to declare an account holder or payee's chapter 4 status (for an entity account holder) or tax residency (for an individual account holder). It exists in the form of official IRS forms of the series $\mathrm{W}-8$ and W-9. In lieu of a withholding certificate, a withholding agent may use a substitute form of a withholding certificate or a written statement. Withholding statements form an integral part of an intermediary withholding certificate.

A self-certification is used to establish whether an account is a U.S. Account (for entity and individual account holders) or an account held by a Nonparticipating Financial Institution (for entity account holders). A selfcertification exists in the form of a withholding certificate or in the form of a similar agreed form (i.e., a substitute form for a withholding certificate). In lieu of a selfcertification, a withholding agent may use "an acceptable self-certification for purposes of Annex I IGA".

Both withholding certificates and self-certifications have one thing in common: They allow a PFFI to reasonably establish an account holders or a payee's chapter 4 status.

The Table 1 is an overview of all kind of forms which are acceptable to establish an account holder's chapter 4 status.

The term documentary evidence is the only term that is commonly used in all legal provisions. Documentary evidence may be required in certain situations in addition to a withholding certificate (or a substitute in any form) to reliably associate an account holder's or payee's chapter 4 status.

The market generally refers to a "self-declaration" as an "acceptable self-certification for purposes of Annex I IGA". In fact, the term "self-declaration" is not an official term-neither under the Treas. Reg. nor under a Model 1 or 2 IGA. Bespoke self-declarations are becoming more prevalent in jurisdictions like the UK where a PFFI needs to ask its account holder about all his tax residencies due to the due diligence requirements of a UK PFFI (see IGA UK-USA, 2012). 
Table 1. Different documents for reliably associating an account holder's chapter 4 status

\begin{tabular}{|c|c|c|c|c|}
\hline Term & Meaning & Treas. Reg. & IGA 1 & IGA 2 \\
\hline Withholding certificate & Certification of a chapter 4 status & $\S 1.1471-1(\mathrm{~b})(148)$ & & \\
\hline $\begin{array}{l}\text { a) Official IRS Forms of the } \\
\text { series W-8 and W-9 }\end{array}$ & $\begin{array}{l}\text { Certification of a chapter } 4 \text { status } \\
\text { with an IRS Form W- } 8, \text { W-9, or } \\
\text { any other certificate }\end{array}$ & $\S 1.1471-1(b)(148)$ & & \\
\hline $\begin{array}{l}\text { b) Substitute form for a } \\
\text { withholding certificate }\end{array}$ & $\begin{array}{l}\text { any other certificate that under the } \\
\text { Code or regulations certifies or } \\
\text { establishes the chapter } 4 \text { status }\end{array}$ & $\begin{array}{l}\S 1.1471-1(b)(148) \\
\text { referring to } \S 1.1471-3(c)(6)(v)\end{array}$ & & \\
\hline c) Written statement & $\begin{array}{l}\text { Simplified form of a certification } \\
\text { of a chapter } 4 \text { status in lieu of a } \\
\text { withholding certificate or substitute } \\
\text { form, must not be used for declaring } \\
\text { a chapter } 3 \text { status }\end{array}$ & $\begin{array}{l}\$ 1.1471-1(b)(150) \text { referring to } \\
\$ 1.1471-3(c)(4), \text { limited to } \\
\S 1.1471-3(d)\end{array}$ & & \\
\hline d) Withholding statement & $\begin{array}{l}\text { Forms an integral part of an } \\
\text { intermediary withholding certificate } \\
\text { and allocates the withholdable } \\
\text { payments to the appropriate } \\
\text { account holders }\end{array}$ & $\S 1.1471-3(\mathrm{c})(3)(\mathrm{iii})(\mathrm{B})$ & & \\
\hline Self-certification & $\begin{array}{l}\text { A certification by the account } \\
\text { holder about his U.S. tax resident status }\end{array}$ & & $\begin{array}{l}\text { e.g.II(B)(1)(4)(a)(1) } \\
\text { annex I }\end{array}$ & $\begin{array}{l}\text { e.g. II(B)(1)(4)(a)(1) } \\
\text { annex I }\end{array}$ \\
\hline $\begin{array}{l}\text { a) Official IRS Forms of the } \\
\text { series W-8 and W-9 }\end{array}$ & an IRS Form & & & \\
\hline $\begin{array}{l}\text { b) Similar agreed form }=a \\
\text { substitute form for a } \\
\text { withholding certificate }\end{array}$ & $\begin{array}{l}\text { Any other certificate that under the Code } \\
\text { or regulations certifies or establishes } \\
\text { the chapter } 4 \text { status }\end{array}$ & & see IRS (2015c) & \\
\hline $\begin{array}{l}\text { c) An acceptable self- } \\
\text { certification for purposes } \\
\text { of Annex I IGA }\end{array}$ & $\begin{array}{l}\text { A self-certification that is accepted by the } \\
\text { IRS from PFFIs from IGA jurisdictions }\end{array}$ & & see IRS (2015d) & \\
\hline Documentary evidence & $\begin{array}{l}\text { Documents, other than a withholding } \\
\text { certificate or written statement, that a } \\
\text { withholding agent is permitted to rely } \\
\text { upon to determine the chapter } 4 \text { status } \\
\text { in certain situations }\end{array}$ & $\S 1.1471-1(b)(32)$ & VI(D) annex I & \\
\hline
\end{tabular}

Another great advantage of a self-declaration is the fact that it may be created in any language, not only in English. That facilitates the chapter 4 declaration for numerous account holders around the globe, who do not understand the English language.

\section{Conclusion}

One main finding of this review article is that a PFFI has always the possibility to have an account holder to declare his chapter 4 status or his tax residency with help of either a withholding certificate or a self-certification, rather than do this classification itself (and thereby risking to do a wrong classification due to inaccurate information).

Another main finding is the fact that PFFIs in absence of a governing IGA must use withholding certificates for such self certifications, whilst PFFIs that are governed under an IGA may elect to use a self-certification in the form of a self-created "acceptable self-certification for purposes of Annex I IGA" in lieu of official IRS forms.

A third main finding is the fact that official IRS forms are neither "stronger" or "more valuable" nor mandatory. A PFFI that is governed under an IGA may always elect to use an "acceptable self-certification for purposes of Annex I IGA" in lieu of official IRS forms. The economic implications by the use of "acceptable self-certification for purposes of Annex I IGA" are: clients do not need to sign under penalties of perjury, PFFIs may create the forms in the local language and in own words and finally, such self-certificaton forms may also be valid self-certifications for purposes of the OECD common reporting standard.

\section{Acknowledgment}

There is no source of financial support, no financial support or relationships that may pose conflict of interest and no technical assistance from anyone.

\section{Funding Information}

There are no funders of this manuscript, it is all the authors work and he did not get any funds from anyone.

\section{Author's Contributions}

The whole review article is my own work without contribution from any other person.

\section{Ethics}

I hereby certify that no part of manuscript reporting original work is being considered for publication in whole or in part elsewhere.

\section{References}

HSBC, 2015. Withholding Statement, n.p., n.d. Internet, HSBC. 
IGA UK-USA, 2012. Intergovernmental Agreement UKUSA (IGA UK-USA): Agreement between the Government of the United States of America and the Government of the United Kingdom of Great Britain and Northern Ireland to improve International Tax Compliance and to Implement FATCA.

IGA CH-USA, 2015. Intergovernmental Agreement CHUSA (IGA CH-USA): Abkommen zwischen der Schweiz und den Vereinigten Staaten von Amerika über die Zusammenarbeit für eine erleichterte Umsetzung von FATCA, SR 0.672.933.63.

IRS, 2014. 26 U.S.C. § 1.1471-1.1474 (Treas. Reg.), FATCA-Regulations and Other Guidance, Department of the Treasury, Internal Revenue Service.
IRS, 2015a. Tax code, regulations and official guidance, n.p., n.d. Internet. IRS.

IRS, 2015b. Withholding certificate forms under IRS sections 1441-1464, n.p., n.d. Internet, IRS.

IRS, 2015c. FATCA-FAQs general, general compliance, Q8, n.p., n.d. Internet, IRS.

IRS, 2015d. FATCA-FAQs general, general compliance, Q9, n.p., n.d. Internet, IRS.

IRS, 2015e. Instructions for the Requester of Forms W8BEN, W-8BEN-E, W-8ECI, W-8EXP and W8IMY, n.p. Internet, IRS. 